\title{
Akademisyenlerin Mesleki Motivasyonları İle İş Tatmini Arasındaki İlișki
}

\section{Salih DEMIR*, Ahmet AKBABA**}

Öz: $\mathrm{Bu}$ araştırmanın amacı; Yüzüncü Yıl Üniversitesinde çalışan akademik personelin mesleki motivasyonları ile iş tatmini arasındaki ilişkinin incelenmesidir. Araştırma, nicel araştırma yöntemlerinin kullanıldığı betimsel bir çalışmadır. Araştırmanın evreni; Yüzüncü Y1l Üniversitesinde çalışan 1318 akademisyenden oluşmaktadır. Evrenin tümüne ölçek uygulanmıştır. Çalışmada üç bölümden oluşan Mesleki Motivasyon Ölçeği ve İş Tatmini ölçeği kullanılmıştır. Elde edilen veriler uygun istatistik programında analiz edilmiştir. Araştırma sonucunda; akademisyenlerin mesleki motivasyonları; mesleki özelikler ve iş yerindeki ilişkiler boyutlarının ortalama motivasyon düzeyinden daha yüksek, yönetim politikaları, öğrenci ve fiziksel koşullar boyutlarının ise daha düşük değerlere sahip oldukları görülmüştür. İş tatmini konusunda ise; öğretim elemanlarının genel iş tatminine yönelik görüşlerinin yaş değişkeni açısından istatistiksel olarak anlamlı farklılık gösterdiği. 40 yaş ve üzeri öğretim elemanlarının 40 yaş ve altı öğretim elemanlarına göre, genel iş tatminlerinin daha yüksek olduğu, ayrıca, katılımcı akademisyenlerin genel iş tatmin düzeylerinin yüksek seviye olduğu ortaya çıkmıştır.

Anahtar Sözcükler: Mesleki Motivasyon, İş Tatmini, Akademisyen, motivasyon, Meslek

\footnotetext{
* Öğrt. Gör. Van Yüzüncü Y1l Üniversitesi, Eğitim Fakültesi, Email: saldem65@ gmail.com, https://orcid.org/0000-0003-0017-154X

*** Doç. Dr. Van Yüzüncü Y1l Üniversitesi, Eğitim Fakültesi, Email: ahmetakbaba13@gmail.com, https://orcid.org/0000-0003-3256-441X
}

$\begin{array}{lll}\text { Gönderim: } 30.06 .2018 & \text { Kabul:06.09.2018 } & \text { Yayın:29.10.2018 }\end{array}$


The Relationship Between Occupational Motivation and Job Satisfaction of The

\title{
Academicians
}

\begin{abstract}
The aim of the study is to examine the relationship between occupational motivation and job satisfaction of the academicians working at Yüzüncü Y1l University. The study is a descriptive study which is one of the quantitative research methods. The population of the study consists of 1318 academicians working at Yüzüncü Y1l University. The scale were administered to the all members of the study population. Occupational Motivation and Job Satisfaction Scale which consists of three sections was employed in the study. 396 scales applied to the study group were included in the study. The obtained data was analyzed by appropriate statistical program. At the end of the study, it seems that occupational motivation of academicians; the dimensions of occupational characteristics and relationship at work are higher than average motivation level while the dimensions of management policies, students, physical conditions have lower values. Regarding job satisfaction, it was found that teaching staff's job satisfaction varies significantly in terms of age and the lecturers at the age of 40 and above have higher job satisfaction than the lecturers under the age of 40 . Moreover, general job satisfaction levels of teaching staffs was determined very high according to the results of the research.
\end{abstract}

Keywords: Occupational Motivation, Job Satisfaction, Academician, Motivation, Occupational

\section{Giriş}

İnsanın evrene hâkim olma çabası sonucunda bir bilgi birikimi meydana gelmiştir. Tek başına birçok iş ile baş edemeyen birey, İşbirliği sonucunda ortaya çıkan sinerji ile daha büyük sistemler kurmuştur. Daha büyük işler başarılmış, hayatı kolaylaştırmak için bilim ve teknoloji üretmiştir. İnsan gücüne olan ihtiyaç, aynı zamanda insanları memnun etme ihtiyacını da doğurmaktadır. İhtiyaçları karşılanan insan ise örgütün verimliliğini ve etkililiğinin artırılması için gerekli gücü göstermeye daha istekli daha arzulu olabilmektedir. Örgütlerde çalışan bireylerin etkili ve verimli çalışması için, ihtiyaçlarının karşılanması, doyurulması, memnun edilmesi ve motivasyon ve iş doyumlarının artırılması örgütler için önemli uğraşlar arasında girmiştir.

Motivasyon bir amacı gerçekleştirmek için işe koyulmadır. Kendisini işe vermektir. İş üzerine odaklanmak bilişsel enerjisini yaptığı işe yoğunlaştırarak sürdürmektir. Bireyin kendi 
isteği ile bir işi yapmaya çalışması iç, dışarıdan herhangi bir kişinin teşvikiyle işe başlayıp işi sonuçlandırmaya çalışması da dış motivasyon olarak ifade edilmektedir. İç motivasyon diş motivasyondan daha etkili olduğundan isteyerek yoğunlaşma sonuç getirici bir uğraş olarak ifade edilebilir.

Akademisyenlerin de diğer tüm meslek gruplarında olduğu gibi, çalışmalarının sağlıklı ve verimli olabilmesi için moral ve motivasyonlarının yerinde olması, işlerini neşe içinde yapmaları, çalıştıkları örgütlerde iş tatminine ulaşmaları büyük önem arz etmektedir. Çünkü akademisyenlerin işlerindeki motivasyonları, iş tatminleri ve verimliliği, yetiştirdikleri öğrencileri de o oranda etkileyebilir. Bir atasözümüzde ifade edildiği gibi ’Ne ekersen onu biçersin’ sözü özellikle işverenlerin elde edeceği ürünün neticesini kendi yaptıklarının ve ektiklerinin sonucudur denilebilir.

Motivasyon, canlıyı bir amaca yönelik hareketini başlatan sürdüren ve elde ettiğinde biten, ya da yeni bir ihtiyaç için başka bir yöne devam eden içten gelen çabalar bileşkesidir. Başka bir tanımda ise motivasyon, bireylerin, belirli bir amacı gerçekleştirmek üzere kendi arzu ve istekleri ile davranış sergilemeleri olarak ifade edilmektedir (Koçel 2001: 154).

Motivasyon Araçları, Yirminci yüzyılın başlarında bilim insanları, motive olmuş davranışın dürtü ya da içgüdüler tarafından ortaya çıktığına inanıyorlardı. Bu inanış zamanla davranışın sadece içgüdü ya da dürtü ile açıklanamayacağı düşüncesiyle bilim adamlarını yeni arayışlara sevk etmiştir. Yapılan çalışmalar ile bireyin davranışlarının türe özgü olarak tanımlanan, doğum ile birlikte kendini belli ettiren davranışlar olmadığı, çok daha sarmal ve karışık bir yapıda olduğu fark edilerek, motivasyon konusu ile ilgili yeni düşünceler ve yorumlar ortaya çıkmıştır (Gürgan, 2014: 296). Çalışanları motive eden birçok faktörden biri de, çalışanın içinden geldiği gibi davranış sergilemesidir. Çalışan bazen kendiliğinden bazen de diştan gelebilecek özendirici faktörlerin etkisi ile harekete başlar. İçten gelen bu faktörler genelde içsel faktör denilen içgüdü ile açıklanmaktadır.

Fizyolojik Motivler. Sosyal Motivler. Bireyde güdüyü oluşturur. Bireyin yaşamındaki güdülenme, yalnızca fizyolojik veya temel olan gereksinimlerin karşılanmasından ibaret değildir. Onaylamak, beğenilmek, sevilmek ve kabullenmek gibi güdüler bireyin yaşamında çok fazla önem taşır. (Kılıç, 2014: 179).

Çalışanların kurumlarda, kurumun amaçlarını gerçekleştirmeye dönük harekete geçmesi, istenilen hedefe yönelmesi ve işi zevkle yapma arzusu kolay olmayan bir süreçtir. Özdemir (2008), 
İş tatmini, örgütlerde çalışanların önemsendiği, değer gördüğü ve örgütlerin önemli bir parçası olarak fark edilmesinin bir sonucu olarak değerlendirilmeye alınmıştır. Çalışanlar tarafindan yürütülen örgütsel faaliyetlerin de bu konuya bir katkısının olduğu bilinmektedir. ABD’de 1897 ile 1904 arasındaki yıllarda sendikaların üye sayısı beş kat artmış ve sendikal mücadele ivme kazanmıştır (Bendix, 1956; s. 265, akt. Sun, 2002).

Çalışanların iş tatmin düzeyini etkileyen faktörleri belirlemeye/anlamaya çalışan uzmanlar çalışanların işine bağlılığını ve sadakatini nelerin etkilediğini ortaya koyarak araştırmacılara yol göstermeye çalışmışlardır. İşinden tatmin olan birey, başta örgütüne, kendisine, ailesine, çevresine ve topluma ciddi katkıları ve yansımalarının olduğu öngörülebilir. İş tatmini, tüm örgütler için hem bireysel hem de örgütsel açıdan önemlidir. Eğinli (2009), tarafından yapılan bir çalışmada, çalışanın iş ve iş ortamı ile ilgili hoşnutluk duyması İş tatmininde ilk sırada yer almaktadır.

$\mathrm{Bu}$ araştırmada; akademisyenlerin, mesleklerini icra ederken karşılaştıkları problemler, ihtiyaç ve beklentilerinin karşılanması, mesleki motivasyon ile iş tatmini arasındaki ilişkinin belirlenmesi ile motivasyon ve iş tatmin düzeylerinin yükseltilmesini engelleyen problemleri tespit etmek ve ortadan kaldırılması için ilgililere önerilerde bulunmak temel problem olarak belirlenmiştir.

\section{Araştırmanın Amacı}

$\mathrm{Bu}$ araştırmanın amacı; akademisyenlerin mesleki motivasyonları ile iş tatminleri arasındaki ilişkiyi belirlemektir. Bu amaçla aşağıdaki sorulara yanıtlar aranmıştır.

1- Akademisyenlerin mesleki motivasyonları ve iş tatminleri ne düzeydedir?

2- Akademisyenlerin mesleki motivasyonları; Mesleki özellikler, yönetim politikaları, işyerinde ilişkiler ve işyerinde fiziksel koşulları alt boyutlarında ne düzeydedir? Ve mesleki motivasyonları; yaşa, cinsiyete, kıdeme eğitim durumuna, çalıştığ 1 birime ve unvana göre farklılık göstermekte midir?

3- Akademisyenlerin mesleki motivasyonları ile iș tatminleri arasındaki ilişski nasildir? 
4- Akademisyenlerin iş tatmin-düzeyleri; Mesleki özellikler, yönetim politikaları, işyerinde ilişkiler ve işyerinde fiziksel koşulları alt boyutlarında ne düzeydedir? Ve mesleki motivasyonları; yaşa, cinsiyete kıdeme eğitim durumuna çalıştığı birime ve unvana göre farkl11ık göstermekte midir?

5- akademisyenlerin mesleki motivasyonları ile iş tatmini arasındaki ilişki nasıldır?

\section{Yöntem}

\section{Araștırmanın Modeli}

Araştırma, nicel araştırma yöntemlerinden betimsel bir çalışmadır. Araştırma, nicel araştırma yöntemlerinden betimsel bir çalışmadır. Akademisyenlerin mesleki motivasyonları ile iş tatmin düzeyleri arasındaki ilişkiyi belirlemeye yönelik olarak genel tarama modellerinden ilişkisel tarama desenleri seçilmiştir. Tarama modelleri geçmişte ya da günümüzde mevcut bir durumu var olduğu haliyle betimlemeyi amaçlayan araştırma modelidir. Araştırmanın konusunu kendi koşulları içinde ve olduğu gibi tanımlar (Karasar, 1995, s. 34).

\section{Evren ve Örneklem;}

Araştırmanın hedef evrenini Yüzüncü Y1l Üniversitesinde görev yapan akademisyenlerin tümünü oluşturmaktadır. Araştırma için öncelikle Yüzüncü Yıl Üniversitesine bağlı yerleşke içinde ve ilçelerde bulunan birimler belirlenmiştir. Yüzüncü Yıl Üniversitesi yerleşkesinde ve ilçelerde 2016-2017 Öğretim yılında görev yapan; 93 profesör, 119 doçent, 462 yardımcı doçent, 138 öğretim görevlisi/okutman/uzman ve 506 araştırma görevlisi olmak üzere toplam 1318 akademisyenin tümüne ulaşılmak istenmiş ancak 563 akademisyene basit tesadüfü yöntemle ulaşılabilmiştir. Ulaşılan akademisyenlerden 430'u ölçekleri doldurmuştur. Ölçeklerin doldurulma oranı \%66 civarında olarak gerçekleşmiştir. Geri dönüş yapan 430 ölçek formundan 396 adedi tam olarak doldurulmuş olup analizler için uygun bulunmuştur.

\section{Akademisyenlere Ait Demografik Değişkenlere İlişkin Bulgular}

Tablo.1: Demografik Değişkenlere İlişskin Frekans Analizleri

\begin{tabular}{llll}
\hline Demografik Değişkenler & & $\mathbf{n}$ & $\mathbf{\%}$ \\
\hline \multirow{2}{*}{ Cinsiyet } & Erkek & 301 & 76 \\
& Kadın & 95 & 24 \\
\hline \multirow{2}{*}{ Yaş } & 40 yaş ve altı & 248 & 62,6 \\
& 40 yaş üstü & 148 & 37,4 \\
\hline Unvan & Arş. Gör. & 109 & 27,5
\end{tabular}




\begin{tabular}{llll}
\hline & Öğr. Gör.-Okut.-Uzm. & 110 & 27,8 \\
& Yrd. Doç. & 114 & 28,8 \\
& Doç. Dr. & 34 & 8,6 \\
& Prof. Dr. & 29 & 7,3 \\
\hline \multirow{3}{*}{ Ĕgitim Durumu } & Lisans & 22 & 5,6 \\
& Y. Lisans & 143 & 36,1 \\
& Doktora & 231 & 58,3 \\
\hline \multirow{3}{*}{ Çalşstı̆ı Birim } & Fakülte & 269 & 67,9 \\
& Yüksekokul & 118 & 29,8 \\
& Diğer & 9 & 2,3 \\
\hline \multirow{3}{*}{ Kıdem } & 10 yıl ve altı kıdem & 242 & 61,1 \\
& $11-20$ yıl kıdem & 85 & 21,5 \\
& 21 yıl ve üzeri kıdem & 69 & 17,4 \\
\hline
\end{tabular}

Tablo 1 incelendiğinde araştırmaya katılan akademisyenlere ilişkin demografik bulgular şu şekildedir; Katılımcı akademisyenlerin \%76'sı erkek (301), \%24'i kadın (95)'dır. Katılımcı akademisyenlerin \% 62,6'sı 40 yaş ve alt1, \% 37,4'ü ise 40 yaşın üzerinde olduğu görülmektedir. Katılımcı akademisyenlerin \%28,8'inin Yrd. Doç., \%27,8'inin Öğr. Gör., Okut., Uzm. \%27.5'inin Arş. Gör., \%8,6'sının Doç. Dr. ve \%7.3'ünün ise Prof. Dr. unvanlarına sahip olduğu görülmektedir. Katılımcı akademisyenlerin \%58,3'ünün doktora, \%36,1'inin yüksek lisans ve \%5,6'sının ise lisans düzeyinde eğitim durumuna sahip oldukları görülmektedir. Katılımcı akademisyenlerin \%67,9’u fakülte çalışanı olarak görülürken \%29,8'i ise yüksekokul çalışanı olarak görülmektedir. Katılımcı akademisyenlerin \%61,1'i 10 y1l ve altı, \%21,5'i 11-20 y1l arası kıdeme sahipken, \%17,4 ise 21 y1l ve üzeri kıdeme sahip durumunda görülmektedir.

\section{Veri Toplama ve Analiz;}

Araştırmada ölçek uygulanmıştır. Ölçekler evreni oluşturan akademik personelin tümüne uygulanmıştır. Ölçek verileri değerlendirilmeden önce elde edilen ölçeklerin uygun bir şekilde yanıtlanıp yanıtlanmadığı kontrol edilerek, uygun şekilde yanıtlanmış olan ölçekler değerlendirmeye alınmıştır. Ölçekler ile elde edilen verilerin açıklayıcı faktör analizi, t-test, anova analizleri ile korelasyon analizleri bilgisayar üzerinde uygun paket programı ile yapılmıştır. 
Kişisel Bilgi Formu: Araştırmada katılımcılara ait demografik bilgilerin belirlenmesi için 'Kişisel Bilgi Formu 'geliştirilmiştir. 6 sorulu Formda, yaş, cinsiyet, eğitim durumu, medeni hal, kıdem, çalıştığı birim ve unvan ile ilgili bilgi amaçlı sorular yer almıştır. Çalışmada kullanılan veriler, Mesleki Motivasyon Ölçeği, Minnesota İş Tatmin Ölçeği ve Kişisel Bilgi Formu katılımcılara elden dağıtılarak toplanmıştır. Araştırmada Zeynel (2014) tarafından geliştirilen 'Mesleki Motivasyon Ölçeği', Weiss ve ark (1967)tarafından geliştirilen 'Minnesota İş Tatmin Ölçeği' ve Kişisel Bilgi Formu' kullanılmıştır. Ölçek, katılımcıların tanıtıcı kişisel bilgilerini içermemesi ve katılımcıların özgüven içinde rahatlıkla cevapladıkları bir araştırma aracıdır. Katılımcıların, aynı soru grubuna kendi cevaplarını verebilmesinden ve çok yüksek miktarda kişiye ulaşılıp uygulandığından, özellikle sosyal alanda çalışma yapan araştırmacılar tarafindan çok tercih edilen veri elde etme tekniğidir.

Mesleki Motivasyon Ölçeği:

Akademisyenler için mesleki motivasyon ölçümünü gerçekleştirmek üzere; Zeynel (2014), tarafından geliştirilen, güvenirlik-geçerlilik analizleri yapılan 50 maddeden oluşan ölçeğin Cronbach alfa değeri, 94.6 gibi yüksek bir değer çıkan ölçeğin geçerli ve güvenilir olduğunu gösteren Mesleki Motivasyon Ölçeği kullanılmıştır.

Araştırmada kullanılan analizler olarak ilk aşamada ilgili boyutların belirlenmesi amacı ile Mesleki Motivasyon Ölçeği ile Faktör Analizi uygulanmıştır. Analiz, istatistiki paket programı ile gerçekleştirilmiştir. Açımlayıcı ve doğrulayıcı Faktör Analizi yapmanın amacı Ölçeklerin geçerlik ve güvenirliklerini incelemektir. Doğrulayıcı Faktör Analizi İlk olarak açımlayıcı faktör analizi ile boyutları belirlenen mesleki motivasyon ölçeği için yapılmıştır. Faktör Analizi Lisrel 8.51 paket programı ile gerçekleştirilmiştir. Zeynel, 2014 tarafından ölçeğin geçerlilik ve güvenilirlik testleri yapılmış cronbach alfa değeri 0,77 , Bizim yaptığımız Beş boyuttan oluşan motivasyon ölçeğinin Faktör analiz sonucunda cronbach alfa değerlerinin, 94,6 ve üzeri değerler aldığı ve iyi bir güvenilirliğe sahip olduğu, ortaya çıkmıştır.

Ayrıca ölçeği geliştiren

İş Tatmini Ölçeği: Bu araştırmada akademisyenlerin iş tatmini ölçmek amacıyla, 1967 yılında Weiss ve ark. Tarafından gerçekleştirilen ve daha sonra aynı kişiler tarafından içsel ve dışsal tatmin durumları ile ilgili maddeler birleştirilerek soru sayısı 100'den 20'ye indirilen Minnesota Tatmin Ölçeği kullanılmıştır. Minnesota İş Tatmini Ölçeği’nin İngilizce' den Türkçe' ye çevirisi 1985 yılında Deniz ve Güliz Gökçora tarafından yapılmış olup, sonraki yıllarda da ölçek ile farklı dilbilimciler tarafından geliştirilmiş ve kullanılması uygun 
bulunmuştur. 20 maddelik Baycan (1985), tarafından Türkçeye uyarlanmıştır. İçsel faktörler için 0,78; dışsal faktörler için, 0,72 olarak çıkmıştır (Zeynel, 2014). Tarafımızdan Ölçeğin geçerlilik ve güvenilirlik testleri yapılmış cronbach alfa değeri 0,77 , cronbach alfa değeri 0,83 olarak çıkmıştır. Bu araştırmada Minnesota İş Tatmini Ölçeği’nin cronbach alfa değeri 0,76 olarak bulunmuştur.

\section{Bulgular}

Akademisyenlerin Mesleki motivasyon toplam puan ve alt boyutlara ilişkin betimsel istatistikler tablo 2 de verilmiştir.

Tablo.2: Mesleki motivasyon toplam puan ve alt boyutlara ilişkin betimsel istatistikler

\begin{tabular}{llll}
\hline & $\mathbf{N}$ & $\bar{x}$ & Ss \\
\hline Mesleki Özellikler & 396 & 3,84 &, 57 \\
\hline Yönetim Politikaları & 396 & 3,16 &, 95 \\
\hline İş Yerinde İlişkiler & 395 & 3,62 &, 88 \\
\hline Öğrenci & & & \\
\hline Fiziksel Koşullar & 396 & 3,31 &, 77 \\
\hline Toplam Motivasyon & 396 & 3,32 &, 95 \\
\hline
\end{tabular}

Tablo 2 incelendiğinde akademisyenler Öncelikle akademisyenlerin mesleki motivasyon düzeyleri ( $\overline{\bar{X}}=3,53, \mathrm{SS}=, 57)$ çıkmıştır. Mesleki motivasyon düzeyini ölçmeye yönelik yapılan betimsel istatistik analiz sonuçlarına göre; Beş boyuttan oluşan motivasyon boyutları içinde akademisyenlerin mesleki özellikler $(\bar{X}=3.84)$ boyutu en yüksek değere sahiptir. Yönetim politikaları $(\bar{X}=3.16)$ boyutu ise en düşük değere sahiptir. bakıldığında ise mesleki özelikler, iş yerinde ilişkiler boyutlarının ortalama motivasyon düzeyinden daha yüksek; yönetim politikaları, öğrenci ve fiziksel koşullar boyutlarının ise daha düşük değerlere sahip oldukları görülmektedir.

Genel olarak bakıldığında ve aritmetik ortalamalar göz önüne alındığında araştırmaya katılan akademisyenlerin motivasyon düzeylerinin birbirlerine yakın olduğu görülmektedir. 
Demografik Değişkenlere Göre Mesleki Motivasyon Toplam, Alt Boyut Ve İş Tatmini Açıklamaya Yönelik Bulgular

Araştırmaya katılan akademisyenlerin mesleki motivasyon düzeyleri, sırasıyla cinsiyet, yaş, kurum, kıdem, eğitim durumu ve unvan başlıklarından oluşan demografik değişkenlere göre ilişkisel olarak değerlendirilmiştir.

Cinsiyet değişkenine göre mesleki motivasyon toplam, alt boyut ve iş tatminine ilişkin $\mathrm{t}$ testi analizi Tablo 3'de verilmiştir.

Tablo.3: Cinsiyet Değişkenine Göre Mesleki Motivasyon Toplam, Alt Boyut Ve İş Tatminine İlişkin T Testi Analizi

\begin{tabular}{|c|c|c|c|c|c|c|}
\hline & Cinsiyet & $N$ & $\overline{\bar{X}}$ & $s s$ & $t$ & $P$ \\
\hline \multirow{2}{*}{ 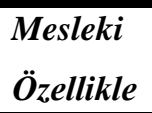 } & Kadın & 95 & 3,82 & 0,56 & \multirow[t]{2}{*}{,- 251} & \multirow[t]{2}{*}{,802 } \\
\hline & Erkek & 301 & 3,84 & 0,57 & & \\
\hline \multirow{2}{*}{$\begin{array}{l}\text { Yönetim } \\
\text { Politikal } \\
\end{array}$} & Kadın & 95 & 3,10 & 0,96 & \multirow[t]{2}{*}{$-1,179$} & \multirow[t]{2}{*}{,240 } \\
\hline & Erkek & 301 & 3,20 & 0,95 & & \\
\hline \multirow{2}{*}{$\begin{array}{l}\dot{I} \boldsymbol{s} \\
\text { Yerinde }\end{array}$} & Kadın & 95 & 3,40 & 0,85 & \multirow[t]{2}{*}{$-2,916$} & \multirow[t]{2}{*}{,004 } \\
\hline & Erkek & 301 & 3,70 & 0,88 & & \\
\hline \multirow{2}{*}{ Öğrenci } & Kadın & 95 & 3,28 & 0,78 & \multirow[t]{2}{*}{,- 412} & \multirow[t]{2}{*}{,681 } \\
\hline & Erkek & 301 & 3,32 & 0,77 & & \\
\hline \multirow{2}{*}{$\begin{array}{l}\text { Fiziksel } \\
\text { Koşullar }\end{array}$} & Kadın & 95 & 3,18 & 1,03 & \multirow[t]{2}{*}{$-1,636$} & \multirow[t]{2}{*}{, 103 } \\
\hline & Erkek & 301 & 3,37 & 0,92 & & \\
\hline \multirow{2}{*}{$\begin{array}{l}\text { Toplam } \\
\text { Motivasy }\end{array}$} & Kadın & 95 & 3,44 & 0,52 & \multirow[t]{2}{*}{$-1,639$} & \multirow[t]{2}{*}{, 102} \\
\hline & Erkek & 301 & 3,55 & 0,58 & & \\
\hline \multirow{2}{*}{$\begin{array}{l}\dot{I} \boldsymbol{s} \\
\text { Tatmini }\end{array}$} & Kadın & 95 & 3,76 & 0,51 & \multirow[t]{2}{*}{,- 903} & \multirow[t]{2}{*}{,367 } \\
\hline & Erkek & 301 & 3,82 & 0,58 & & \\
\hline
\end{tabular}

Tablo 3'te görüldüğü gibi motivasyon alt boyutlarından iş yerinde ilişkiler boyutunda, kadın akademisyenler ile erkek akademisyenlerin görüşleri arasında anlamlı farklılık görülmüştür $\left(\mathrm{t}_{(95,301}=-2,916, \mathrm{p}<.05\right)$. Aritmetik ortalamaya bakıldığında kadın akademisyenlerin $\left(\bar{X}_{=}=3.40\right)$, erkek akademisyenlere $(\overline{\mathcal{X}}=3.70)$ oranla, motivasyonun iş yerinde ilişkiler boyutuna daha az katılmışlardır. Bununla birlikte motivasyon toplam puan ve motivasyon alt boyutlarına göreceli olarak kadın akademisyenler erkek akademisyenlere göre daha az katılmışlardır. Katılımcıların iş tatmin düzeylerine bakıldığında, kadın akademisyenler ile erkek akademisyenlerin görüşleri arasında anlamlı farklılık görülmemiştir ( $\mathrm{p}>.05)$. Bununla birlikte iş tatmin aritmetik ortalamalar incelendiğinde göreceli olarak kadın akademisyenlerin erkek akademisyenlere göre iş tatmin düzeyleri daha düşük düzeydedir. 
Yaş Değişkenine Göre Mesleki Motivasyon Toplam, Alt Boyut ve İş Tatminine

İlişkin T testi Analizi tablo 4 de verilmiştir

Tablo.4: Yaş Değişkenine Göre Mesleki Motivasyon Toplam, Alt Boyut ve İş Tatminine İlişkin T Testi Analizi

\begin{tabular}{|c|c|c|c|c|c|c|}
\hline & Yaş & $n$ & $\overline{\mathbf{x}}$ & $s s$ & $t$ & $p$ \\
\hline \multirow{2}{*}{ Mesleki Özellikler } & 40 yaş ve altı & 248 & 3,82 & 0,57 &,- 493 &, 622 \\
\hline & 40 yaş ve üstü & 148 & 3,85 & 0,56 & & \\
\hline \multirow{2}{*}{ Yönetim Politikaları } & 40 yaş ve altı & 248 & 3,03 & 0,96 & $-3,501$ & ,001 \\
\hline & 40 yaș ve üstü & 148 & 3,38 & 0,90 & & \\
\hline \multirow{2}{*}{ İş Yerinde İlişkiler } & 40 yaş ve altı & 248 & 3,57 & 0,92 & $-1,531$ &, 127 \\
\hline & 40 yaş ve üstü & 148 & 3,71 & 0,81 & & \\
\hline \multirow{2}{*}{ Öğrenci } & 40 yaş ve altı & 248 & 3,26 & 0,77 & $-1,706$ & ,089 \\
\hline & 40 yaş ve üstü & 148 & 3,40 & 0,77 & & \\
\hline \multirow{2}{*}{ Fiziksel Koşullar } & 40 yaş ve alt1 & 248 & 3,18 & 0,98 & $-4,020$ &, 000 \\
\hline & 40 yaş ve üstü & 148 & 3,57 & 0,84 & & \\
\hline \multirow{3}{*}{ Toplam Motivasyon } & 40 yıl ve alt1 & 248 & 3,46 & 0,56 & $-2,911$ & ,004 \\
\hline & 40 yaş ve üstü & 148 & 3,63 & 0,57 & & \\
\hline & 40 yıl ve alt1 & 248 & 3,74 & 0,58 & $-2,789$ & ,006 \\
\hline İs Tatmini & 40 y1l ve üstü & 148 & 3,91 & 0,51 & & \\
\hline
\end{tabular}

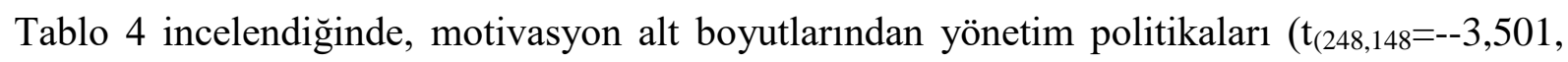
$\mathrm{p}<.05)$ ve fiziksel koşullar $\left(\mathrm{t}_{(248,148}=-4,020, \mathrm{p}<.05\right)$ boyutlarında katılımcı akademisyenlerin yaşlarına göre anlamlı farklılık görülmüştür. Aritmetik ortalamaya bakıldığında 40 yıl ve altı yaşa sahip olan akademisyenlerin $(\overline{\bar{X}}=3.03), 40$ yıl ve üstü yaşa sahip olan akademisyenlere göre $(\bar{X}=3.38)$ motivasyonun yönetim politikaları boyutuna daha az katılmışlardır. Ayrıca aritmetik ortalamaların fiziksel koşullar boyutuna bakıldığında, 40 yıl ve altı yaşa sahip olan akademisyenler $(\bar{X}=3.18), 40$ y1l ve üstü yaşa sahip olan akademisyenlere göre $(\bar{X}=3.57)$ motivasyonun fiziksel koşullar boyutuna daha az katılmışlardır. Toplam motivasyon $\left(\mathrm{t}_{(248,148}=-2,911, \mathrm{p}<.05\right)$ puanı olarak bakıldığında ise katılımcı akademisyenlerin yaşlarına göre anlamlı farklılık görülmüştür. Aritmetik ortalamaya bakıldığında 40 yıl ve altı yaşa sahip olan akademisyenlerin $(\bar{X}=3.46), 40$ y1l ve üstü yaşa sahip olan akademisyenlere $(\bar{X}=3.63)$ göre toplam motivasyon düzeyine daha az katıldıkları saptanmıştır. Bununla birlikte motivasyon toplam puan ve motivasyon alt boyutlarına bakıldığında göreceli olarak 40 yaş ve altı akademisyenlerin 40 yaş ve üzeri akademisyenlere göre daha az katılmışlardır. 
Katılımcı akademisyenlerin iş tatmin $\left(\mathrm{t}_{(248,148}=-2,789, \mathrm{p}<.05\right)$ düzeylerine bakıldığında ise, katılımcı akademisyenlerin yaşlarına göre anlamlı farklılık görülmüştür. Aritmetik ortalamalar incelendiğinde, 40 yıl ve altı yaşa sahip olan akademisyenlerin $(\overline{\bar{X}}=3.74), 40$ yıl ve üstü yaşa sahip olan akademisyenlere $(\overline{\mathbb{X}}=3.91)$ göre iş tatmin düzeylerine daha az katıldıkları saptanmıştır. Mesleki motivasyon düzeyinde ortaya çıkan yaş faktörüne bağlı farklılık, iş tatmininde de görülmüştür. Akademisyenlerin iş tatmin düzeylerinin de yaşa göre anlamlı farklılık göstermesi, yaşın ilerlemesi ile birlikte iş tatmin düzeyinin artış göstermesi olarak ifade edilmiştir. Çünkü işin ve iş ortamının çalışanda oluşturduğu his, çalışanın işine karşı iç dünyasındaki hoşnutluk ya da hoşnutsuzluk ileri yaş boyutunun etkisi ile daha da belirginleşmektedir denilebilir.

Birim Değişkenine Göre Mesleki Motivasyon Toplam, Alt Boyut ve İş Tatminine

İlişkin T Testi Analizi tablo 5 te verilmiştir.

Tablo. 5: Birim Değişkenine Göre Mesleki Motivasyon Toplam, Alt Boyut ve İş Tatminine İlişkin T Testi Analizi

\begin{tabular}{|c|c|c|c|c|c|c|}
\hline & Kurum & $N$ & $\overline{\mathbf{x}}$ & Ss & $T$ & $p$ \\
\hline \multirow{2}{*}{ Mesleki Özellikler } & Fakülte & 269 & 3,88 & 0,56 & \multirow[t]{2}{*}{1,744} & \multirow[t]{2}{*}{, 082} \\
\hline & Yüksekokul & 118 & 3,77 & 0,59 & & \\
\hline \multirow[t]{2}{*}{ Yönetim Politikaları } & Fakülte & 269 & 3,13 & 0,97 & \multirow[t]{2}{*}{$-1,382$} & \multirow[t]{2}{*}{,168 } \\
\hline & Yüksekokul & 118 & 3,28 & 0,89 & & \\
\hline \multirow{2}{*}{ İş Yerinde İlişkiler } & Fakülte & 269 & 3,57 & 0,93 & \multirow[t]{2}{*}{$-1,923$} & \multirow[t]{2}{*}{,077 } \\
\hline & Yüksekokul & 118 & 3,75 & 0,76 & & \\
\hline \multirow[t]{2}{*}{ Ö̆ğrenci } & Fakülte & 269 & 3,30 & 0,77 & \multirow[t]{2}{*}{,- 979} & \multirow[t]{2}{*}{,328 } \\
\hline & Yüksekokul & 118 & 3,38 & 0,78 & & \\
\hline \multirow{2}{*}{ Fiziksel Koşullar } & Fakülte & 269 & 3,44 & 0,91 & \multirow[t]{2}{*}{3,298} & \multirow[t]{2}{*}{,001 } \\
\hline & Yüksekokul & 118 & 3,09 & 1,02 & & \\
\hline \multirow{2}{*}{ Toplam Motivasyon } & Fakülte & 269 & 3,55 & 0,56 & \multirow[t]{2}{*}{,466 } & \multirow[t]{2}{*}{,641 } \\
\hline & Yüksekokul & 118 & 3,52 & 0,59 & & \\
\hline \multirow[t]{2}{*}{ İş Tatmini } & Fakülte & 269 & 3,81 & 0,57 & \multirow[t]{2}{*}{, 359} & \multirow[t]{2}{*}{,720 } \\
\hline & Yüksekokul & 118 & 3,79 & 0,53 & & \\
\hline
\end{tabular}

Tablo 5'te görüldüğü gibi motivasyon alt boyutlarından yalnızca fiziksel koşullarda birim değişkenine göre anlamlı farklılık görülmüştür $\left(\mathrm{t}_{(269,118)}=3,298, \quad \mathrm{p}<.05\right)$. Aritmetik ortalamalarına bakıldığında yüksekokulda çalışan akademisyenlerin ( $\bar{X}=3.09$ ), fakültede çalışan akademisyenlere $(\overline{\bar{X}}=3.44)$ göre motivasyonun fiziksel koşullar boyutuna daha az katılmışlardır. Aynı örgütte fakat farklı birimlerde çalışanların iş tatmini düzeylerinde farklık ortaya çıkmıştır. 
Kıdem Değişkenine Göre Mesleki Motivasyon Toplam, Alt Boyut ve İş Tatminine

İlişkin Tek Yönlü Varyans Analizi tablo 6 da verilmiştir.

Tablo.6: Kıdem Değişkenine Göre Mesleki Motivasyon Toplam, Alt Boyut ve İş Tatminine İlişkin Tek Yönlü Varyans Analizi

\begin{tabular}{|c|c|c|c|c|c|c|c|c|}
\hline & Kidem & $N$ & $\overline{\mathbf{x}}$ & $S$ & Kareler & $F$ & $P$ & Fark \\
\hline \multirow{4}{*}{ Mesleki Özellikler } & 10 y1l ve alt1 & 242 & 3,84 & 0,55 & \multirow[t]{4}{*}{, 057} & \multirow[t]{4}{*}{, 175} & \multirow{4}{*}{839} & \\
\hline & $11-20$ y1l & 85 & 3,80 & 0,60 & & & & \\
\hline & $21 \quad$ y1l ve & 69 & 3,85 & 0,58 & & & & \\
\hline & Toplam & 396 & 3,84 & 0,57 & & & & \\
\hline \multirow{4}{*}{$\begin{array}{l}\text { Yönetim } \\
\text { Politikaları }\end{array}$} & 10 y1l ve alt1 & 242 & 3,11 & 0,95 & \multirow[t]{4}{*}{2,080} & \multirow[t]{4}{*}{2,306} & \multirow[t]{4}{*}{, 101} & \\
\hline & $11-20$ y1l & 85 & 3,12 & 0,97 & & & & \\
\hline & $21 \quad \mathrm{y} 11$ & 69 & 3,38 & 0,92 & & & & \\
\hline & Toplam & 396 & 3,16 & 0,95 & & & & \\
\hline \multirow{4}{*}{ İş Yerinde İlişkiler } & 10 y1l ve alt1 & 242 & 3,66 & 0,87 & \multirow[t]{4}{*}{2,483} & \multirow[t]{4}{*}{3,242} & \multirow[t]{4}{*}{, $040^{*}$} & \multirow[t]{4}{*}{$3>2$} \\
\hline & $11-20$ y1l & 84 & 3,42 & 0,97 & & & & \\
\hline & $21 \quad$ y1l ve & 69 & 3,75 & 0,78 & & & & \\
\hline & Toplam & 395 & 3,62 & 0,88 & & & & \\
\hline \multirow{4}{*}{ Öğrenci } & 10 y1l ve alt1 & 242 & 3,29 & 0,79 & \multirow[t]{4}{*}{1,091} & \multirow[t]{4}{*}{1,846} & \multirow[t]{4}{*}{,159 } & \\
\hline & $11-20$ y1l & 85 & 3,24 & 0,76 & & & & \\
\hline & $21 \quad$ y1l ve & 69 & 3,46 & 0,71 & & & & \\
\hline & Toplam & 396 & 3,31 & 0,77 & & & & \\
\hline \multirow{4}{*}{ Fiziksel Koşullar } & 10 y1l ve alt1 & 242 & 3,21 & 1,00 & \multirow[t]{4}{*}{5,278} & \multirow[t]{4}{*}{6,022} & \multirow[t]{4}{*}{, $003 *$} & \multirow[t]{4}{*}{$3>1$} \\
\hline & $11-20 \mathrm{y} 1 \mathrm{l}$ & 85 & 3,40 & 0,84 & & & & \\
\hline & $21 \quad \mathrm{y} 11$ & 69 & 3,63 & 0,82 & & & & \\
\hline & Toplam & 396 & 3,32 & 0,95 & & & & \\
\hline \multirow{4}{*}{$\begin{array}{l}\text { Toplam } \\
\text { Motivasyon }\end{array}$} & 10 y1l ve alt1 & 242 & 3,51 & 0,55 & \multirow[t]{4}{*}{,801 } & \multirow[t]{4}{*}{2,487} & \multirow[t]{4}{*}{, 084} & \\
\hline & $11-20$ y1l & 84 & 3,48 & 0,61 & & & & \\
\hline & $21 \quad \mathrm{y} 1 \mathrm{l}$ & 69 & 3,66 & 0,57 & & & & \\
\hline & Toplam & 395 & 3,52 & 0,57 & & & & \\
\hline \multirow{4}{*}{ İş Tatmini } & 10 y1l ve alt1 & 242 & 3,77 & 0,58 & \multirow[t]{4}{*}{,555 } & \multirow[t]{4}{*}{1,769} & \multirow[t]{4}{*}{, 172} & \\
\hline & $11-20 \mathrm{y} 1 \mathrm{l}$ & 85 & 3,81 & 0,54 & & & & \\
\hline & $21 \quad \mathrm{y} 11$ & 69 & 3,91 & 0,53 & & & & \\
\hline & Toplam & 396 & 3,80 & 0,56 & & & & \\
\hline
\end{tabular}

Tablo 6 incelendiğinde kıdem değişkenine göre; mesleki özellikler, yönetim politikaları, öğrenci alt boyutları ve toplam motivasyonda katılımcıların görüşleri arasında anlamlı bir fark bulunmamıştır ( $\mathrm{p}>.05)$. 
İş yerindeki ilişkiler ve fiziksel koşullar alt boyutunda kıdem değişkenine göre katılımcıların görüşleri arasında anlamlı farklılık bulunmuştur $(\mathrm{p}<.05)$. Farkın kaynağını bulmaya yönelik yapılan Tukey’s B testi sonucunda 11-20 yıl arası kıdem grubunda olan akademisyenlerin $\left(\bar{X}_{\bar{X}}=\right.$ 3.42), 21 yıl ve üzeri kıdem grubunda $(\overline{\bar{X}}=3.75)$ olan katılımcı akademisyenlere göre iş yerindeki ilişkileri boyutuna daha az katılmışlardır. Diğer taraftan 10 yıl ve altı kıdem grubunda olan katılımcı akademisyenlerin $(\overline{\bar{X}}=3.21), 21$ yıl ve üzeri kıdem grubunda $(\overline{\bar{X}}=$ 3.63) olan katılımcı akademisyenlere göre fiziksel koşullar boyutuna daha az katılmışlardır.

Akademisyenlerin iş tatmin düzeylerine bakıldığında ise, katılımcı akademisyenlerin görüşleri arasında anlamlı bir fark bulunmamıştır ( $\mathrm{p}>.05)$. Göreceli olarak aritmetik ortalamalara bakıldığında ise 21 yıl ve üzeri kıdem grubundaki katılımcı akademisyenlerin diğer gruplara göre iş tatmin boyutuna daha fazla katıldıkları görülmektedir. Başka bir ifade ile çalışanda k1dem artıkça iş tatminin de artış gösterdiği görülmüştür.

Eğitim Durumu Değişkenine Göre Mesleki Motivasyon Toplam, Alt Boyut ve İş Tatminine İlişkin Tek Yönlü Varyans Analizi Tablo 7 de verilmiştir.

Tablo.7: Eğitim Durumu Değişkenine Göre Mesleki Motivasyon Toplam, Alt Boyut ve İş Tatminine İlişkin Tek Yönlü Varyans Analizi

\begin{tabular}{|c|c|c|c|c|c|c|c|c|}
\hline & Ĕgitim & $N$ & & $S S$ & Kareler & $F$ & $P$ & Fark \\
\hline & Durumu. & & $\overline{\mathbf{x}}$ & & ortalame & & & \\
\hline & Lisans & 22 & 3,84 & 0,60 & ,379 & 1,176 & ,310 & \\
\hline & Yüksek & 143 & 3,78 & 0,59 & & & & \\
\hline Özellikler & Doktora & 231 & 3,87 & 0,55 & & & & \\
\hline & Toplam & 396 & 3,83 & 0,57 & & & & \\
\hline Yönotim & Lisans & 22 & 3,00 & 0,91 & ,387 &, 425 & ,654 & \\
\hline & Yüksek & 143 & 3,14 & 1,00 & & & & \\
\hline Politikaları & Doktora & 231 & 3,19 & 0,93 & & & & \\
\hline & Toplam & 396 & 3,16 & 0,95 & & & & \\
\hline & Lisans & 22 & 3,70 & 0,80 & 1,498 & 1,943 &, 145 & \\
\hline Yerinde & Yüksek & 143 & 3,73 & 0,90 & & & & \\
\hline İlişkiler & Doktora & 230 & 3,55 & 0,87 & & & & \\
\hline & Toplam & 395 & 3,62 & 0,88 & & & & \\
\hline & Lisans & 22 & 3,15 & 0,91 & ,984 & 1,664 & ,191 & \\
\hline Öğgrenci & Yüksek & 143 & 3,24 & 0,85 & & & & \\
\hline & Doktora & 231 & 3,37 & 0,70 & & & & \\
\hline & Toplam & 396 & 3,31 & 0,77 & & & & \\
\hline Fiziksel & Lisans & 22 & 2,74 & 1,07 & 6,303 & 7,235 &, $001 *$ & $3>1$ \\
\hline & Yüksek & 143 & 3,22 & 0,98 & & & & \\
\hline
\end{tabular}




\begin{tabular}{|c|c|c|c|c|c|c|c|}
\hline \multirow[t]{2}{*}{ Koşullar } & Doktora & 231 & 3,44 & 0,89 & & & \\
\hline & Toplam & 396 & 3,32 & 0,95 & & & \\
\hline \multirow[b]{2}{*}{ Toplam } & Lisans & 22 & 3,40 & 0,51 & \multirow[t]{4}{*}{,396 } & \multirow{4}{*}{\multicolumn{2}{|c|}{1,223}} \\
\hline & Yüksek & 143 & 3,49 & 0,62 & & & \\
\hline \multirow[t]{2}{*}{ Motivasyon } & Doktora & 230 & 3,56 & 0,54 & & & \\
\hline & Toplam & 395 & 3,52 & 0,57 & & & \\
\hline \multirow{4}{*}{ İş Tatminu } & Lisans & 22 & 3,84 & 0,41 & \multirow[t]{4}{*}{,371 } & \multirow[t]{4}{*}{1,180} & \multirow[t]{4}{*}{,308 } \\
\hline & Yüksek & 143 & 3,75 & 0,60 & & & \\
\hline & Doktora & 231 & 3,84 & 0,55 & & & \\
\hline & Toplam & 396 & 3,80 & 0,56 & & & \\
\hline
\end{tabular}

Tablo 7 incelendiğinde eğitim durumu değişkenine göre; mesleki özellikler, yönetim politikaları, iş yerinde ilişkiler, öğrenci alt boyutları ve toplam motivasyonda katılımcı akademisyenlerin görüşleri arasında anlamlı bir fark bulunmamıştır (p>.05). Akademisyenlerin fiziksel koşullar alt boyutu incelendiğinde, eğitim durumu değişkenine göre katılımcı akademisyenlerin görüşleri arasında anlamlı farklılık bulunmuştur $(\mathrm{p}<.05)$. Farkın kaynağını bulmaya yönelik yapılan Tukeyb testi sonucunda lisans düzeyi eğitim grubunda olan katılımcı akademisyenlerin $(\overline{\bar{X}}=2.74)$, doktora düzeyi eğitim grubunda $(\overline{\bar{X}}=$ 3.44) olan katılımcı akademisyenlere göre fiziksel koşullar boyutuna daha az katıldıkları görülmüştür. Göreceli olarak aritmetik ortalamalara bakıldığında doktora düzeyi eğitim grubundaki katılımcı akademisyenlerin diğer gruplara göre motivasyon alt boyut ve toplam motivasyona daha fazla katılmışlardır.

Unvan Değişkenine Göre Mesleki Motivasyon Toplam, Alt Boyut ve İş Tatminine İlişkin Tek Yönlü Varyans Analiz tablo 8 de verilmiştir.

Tablo.8: Unvan Değişkenine Göre Mesleki Motivasyon Toplam, Alt Boyut ve İş Tatminine İlişkin Tek Yönlü Varyans Analizi 
YYÜ Eğitim Fakültesi Dergisi (YYU Journal of Education Faculty), 2018; 15(1):1256-1286, http://efdergi.yyu.edu.tr

\begin{tabular}{|c|c|c|c|c|c|c|c|c|}
\hline \multirow{7}{*}{$\begin{array}{l}\text { Mesleki } \\
\text { Özellikler }\end{array}$} & Unvan & $N$ & $\overline{\mathbf{x}} \quad S s$ & & Kareler & $F$ & $p$ & Fark \\
\hline & Arș. Uor. & $\frac{74}{109}$ & 3,75 & 0,62 & \multirow[t]{6}{*}{1,129} & \multirow[t]{6}{*}{3,595} & \multirow[t]{6}{*}{, 007} & \multirow[t]{6}{*}{$=4$} \\
\hline & Öğr.Gör- & 110 & 3,76 & 0,57 & & & & \\
\hline & Yrd.Doç. & 114 & 3,92 & 0,50 & & & & \\
\hline & Doç.Dr. & 34 & 4,10 & 0,47 & & & & \\
\hline & Prof.Dr. & 29 & 3,79 & 0,59 & & & & \\
\hline & Toplam & 396 & 3,84 & 0,57 & & & & \\
\hline \multirow{6}{*}{$\begin{array}{l}\text { Yönetim } \\
\text { Politikalart }\end{array}$} & Arş. Gör. & 109 & 2,94 & 1,03 & \multirow[t]{6}{*}{1,984} & \multirow[t]{6}{*}{2,212} & \multirow[t]{6}{*}{,067 } & \\
\hline & Öğr.Gör- & 110 & 3,24 & 0,91 & & & & \\
\hline & Yrd.Doç. & 114 & 3,22 & 0,88 & & & & \\
\hline & Doç.Dr. & 34 & 3,29 & 1,01 & & & & \\
\hline & Prof.Dr. & 29 & 3,32 & 0,94 & & & & \\
\hline & Toplam & 396 & 3,16 & 0,95 & & & & \\
\hline \multirow{6}{*}{$\begin{array}{l}\dot{I} \text { I̧s } \quad \text { Yerinde } \\
\text { İlişkiler }\end{array}$} & Arş. Gör. & 109 & 3,56 & 0,97 & \multirow[t]{6}{*}{1,542} & \multirow[t]{6}{*}{2,011} & \multirow[t]{6}{*}{,092 } & \\
\hline & Öğr.Gör- & 110 & 3,80 & 0,78 & & & & \\
\hline & Yrd.Doç. & 114 & 3,56 & 0,81 & & & & \\
\hline & Doç.Dr. & 34 & 3,67 & 1,00 & & & & \\
\hline & Prof.Dr. & 28 & 3,38 & 0,94 & & & & \\
\hline & Toplam & 395 & 3,62 & 0,88 & & & & \\
\hline \multirow{6}{*}{ Öğrenci } & Arş. Gör. & 109 & 3,12 & 0,85 & \multirow[t]{6}{*}{1,441} & \multirow[t]{6}{*}{2,465} & \multirow[t]{6}{*}{, $045^{*}$} & \multirow[t]{6}{*}{$4>1$} \\
\hline & Öğr.Gör- & 110 & 3,36 & 0,80 & & & & \\
\hline & Yrd.Doç. & 114 & 3,40 & 0,71 & & & & \\
\hline & Doç.Dr. & 34 & 3,46 & 0,58 & & & & \\
\hline & Prof.Dr. & 29 & 3,31 & 0,61 & & & & \\
\hline & Toplam & 396 & 3,31 & 0,77 & & & & \\
\hline \multirow{6}{*}{$\begin{array}{l}\text { Fiziksel } \\
\text { Koşullar }\end{array}$} & Arş. Gör. & 109 & 3,16 & 1,02 & \multirow[t]{6}{*}{2,898} & \multirow[t]{6}{*}{3,300} & \multirow[t]{6}{*}{,011* } & \multirow[t]{6}{*}{$5>1$} \\
\hline & Öğr.Gör- & 110 & 3,20 & 0,97 & & & & \\
\hline & Yrd.Doç. & 114 & 3,41 & 0,86 & & & & \\
\hline & Doç.Dr. & 34 & 3,62 & 0,97 & & & & \\
\hline & Prof.Dr. & 29 & 3,66 & 0,70 & & & & \\
\hline & Toplam & 396 & 3,32 & 0,95 & & & & \\
\hline & Arş. Gör. & 109 & 3,40 & 0,60 & ,891 & 2,798 & & $4>1$ \\
\hline & Öğr.Gör- & 110 & 3,53 & 0,59 & & &, $026^{*}$ & \\
\hline Ioplam & Yrd.Doç. & 114 & 3,59 & 0,51 & & & & \\
\hline Motivasyon & Doç.Dr. & 34 & 3,72 & 0,53 & & & & \\
\hline & Prof.Dr. & 28 & 3,55 & 0,58 & & & & \\
\hline & Toplam & 395 & 3,53 & 0,57 & & & & \\
\hline & Arş. Gör. & 109 & 3,66 & 0,64 & 1,035 & 3,366 &, $010 *$ & $4>1$ \\
\hline & Öğr.Gör- & 110 & 3,83 & 0,53 & & & & \\
\hline & Yrd.Doç. & 114 & 3,84 & 0,52 & & & & \\
\hline & Doç.Dr. & 34 & 4,01 & 0,52 & & & & \\
\hline Iş Tatmini & Prof.Dr. & 29 & 3,88 & 0,47 & & & & \\
\hline & Tonlam & 396 & 3.80 & 0.56 & & & & \\
\hline
\end{tabular}


Tablo 8 incelendiğinde unvan değişkenine göre; yönetim politikaları ve iş yerindeki ilişkiler alt boyutlarında katılımcıların görüşleri arasında anlamlı bir fark bulunmamıştır ( $\mathrm{p}>.05$ ). Mesleki özellikler, öğrenci ve fiziksel koşullar alt boyutları ve toplam motivasyonda unvan değişkenine göre katılımcıların görüşleri arasında anlamlı farklılık bulunmuştur $(\mathrm{p}<.05)$. Farkın kaynağını bulmaya yönelik yapılan Tukey'b testi sonucunda Doç. Dr. unvanına sahip katılımcı akademisyenlerin $(\bar{X}=4.10)$, diğer katılımcılara göre mesleki özellikler boyutuna daha fazla katılmışlardır. Arş. Gör. Unvanına sahip katılımcı akademisyenlerin $(\overline{\bar{X}}=3.12)$, Doç. Dr. unvanına sahip katılımcı akademisyenlere $(\overline{\bar{X}}=3.46)$ göre öğrenci boyutuna daha az katılmışlardır. Yine Arş. Gör. Unvanına sahip katılımcı akademisyenler ( $\overline{\bar{X}}=3.16)$, Prof. Dr. unvanına sahip katılımcı akademisyenlere $(\overline{\bar{X}}=3.66)$ göre fiziksel koşullar boyutuna daha az katılmışlardır.

Toplam motivasyonda Arş. Gör. Unvanına sahip katılımcı akademisyenlerin $\quad(\overline{\bar{X}}=3.40)$, Doç. Dr. unvanına sahip katılımcı akademisyenlere $(\overline{\bar{X}}=3.46)$ göre bu boyuta daha az katıldıkları görülmektedir. $\mathrm{Bu}$ boyutta ortaya çıkan farkl1lık, unvan yükseldikçe mesleki motivasyon düzeyinin de artığı ile ilgilidir. Mesleki özellikler, öğrenci ve fiziksel koşullar alt boyutlarındaki bu fark daha çok mesleki gelişim ve deneyim ile açıklanabilir. Mesleki motivasyon düzeyleri düşük olan ve daha işin başında sayılan Arş. Gör. ise gelecek ile ilgili kariyer planlaması sürecinde çekilen/görülen zorluklar, karşılaştıkları sorunlara pratik çözüm bulma yetersizliği, öğrenciler ile aralarındaki iletişim zayıflığı, meslekteki tecrübesizlik ve karşılanmayan ihtiyaçlar Arş. Gör. mesleki motivasyonlarını düşürebilmektedir. Aynı şekilde Öğr. Gör. Unvanına sahip akademisyenler de fiziksel koşullar boyutuna Arş. Gör. yakın bir düzeyde katılım sağlamışlardır. Özellikle Öğr. Gör. ağır ders yükünden dolayı kariyer planlamasını ertelemeleri, yükünün verdiği dezavantaj ile akademik çalışmalar yapamama, diğer akademisyenler gibi unvan olarak yükselememe ve yönetimlerin de akademisyenlere dağıttığı, ofis, araç-gereç, materyal, ofis donanımı vb. durumlarda akademik unvana göre tercihte bulunması, Öğr. Gör. de motivasyon düzeyinde düşüklük meydana getirdiği söylenilebilir

Mesleki Motivasyon Toplam, Alt Boyu İle İş Tatmini Arasındaki İlişkiyi Belirlemeye Yönelik Pearson Korelasyon Analizi ve Bulgular. 
Tablo.9: Mesleki Motivasyon Toplam, Alt Boyu İle İş Tatmini Arasındaki İlişkiyi Belirlemeye Yönelik Pearson Çarpım Momentler Korelasyon Analizi ve Bulgular

\begin{tabular}{lllllll}
\hline Mesleki & Yönetim & İş̧ & Öğrenci & Fiziksel & Motivasyon & İş \\
Özellikler & Politikaları & Yerinde & & Koşullar & & Tatmini \\
& & & & &
\end{tabular}

\begin{tabular}{|c|c|c|c|c|c|c|c|c|}
\hline Mesleki & Pearson & 1 &, $465 * *$ & ,406** &, $491 * *$ &, $326 * *$ & ,778** &, $551 * *$ \\
\hline Özellikler & Correla & & & & & & & \\
\hline
\end{tabular}

\begin{tabular}{|c|c|c|c|c|c|c|c|}
\hline $\begin{array}{l}\text { Sig. } \\
\text { tailed) }\end{array}$ & & ,000 & , 000 & ,000 & ,000 & ,000 & ,000 \\
\hline Pearson & ,465** & 396 & 395 & 396 & 396 & 395 & 396 \\
\hline
\end{tabular}

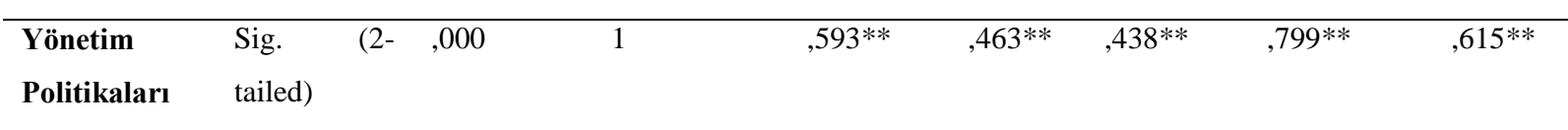

\begin{tabular}{|c|c|c|c|c|c|c|c|}
\hline $\mathrm{N}$ & 396 & & ,000 & , 000 & ,000 & ,000 & ,000 \\
\hline Pearson & ,406** & 396 & 395 & 396 & 396 & 395 & 396 \\
\hline
\end{tabular}

\begin{tabular}{|c|c|c|c|c|c|c|c|c|}
\hline \multirow[t]{4}{*}{$\begin{array}{l}\text { İş Yerinde } \\
\text { İlişsiler }\end{array}$} & $\begin{array}{l}\text { Sig. } \\
\text { tailed) }\end{array}$ & ,000 &, $593 * *$ & 1 & ,349** & ,373** &, $727 * *$ &, $595 * *$ \\
\hline & $\mathrm{N}$ & 396 & ,000 & & ,000 & ,000 & ,000 & ,000 \\
\hline & Pearson & ,491** & 396 & 395 & 396 & 396 & 395 & 396 \\
\hline & Correlation & & & & & & & \\
\hline
\end{tabular}

\begin{tabular}{|c|c|c|c|c|c|c|c|c|}
\hline \multirow[t]{4}{*}{ Öğrenci } & $\begin{array}{l}\text { Sig. } \\
\text { tailed })\end{array}$ & ,000 &, $463 * *$ & ,349** & 1 &, $332 * *$ & ,693** & ,405** \\
\hline & $\mathrm{N}$ & 396 & ,000 & ,000 & & ,000 & ,000 & ,000 \\
\hline & Pearson &, $326 * *$ & 396 & 395 & 396 & 396 & 395 & 396 \\
\hline & Correlation & & & & & & & \\
\hline \multirow{5}{*}{$\begin{array}{l}\text { Fiziksel } \\
\text { Koşullar }\end{array}$} & Sig. & ,000 &, $438 * *$ &, $373 * *$ &, $332 * *$ & 1 &, $665 * *$ &, $538 * *$ \\
\hline & tailed) & & & & & & & \\
\hline & $\mathrm{N}$ & 396 & ,000 & , 000 & ,000 & & , 000 & , 000 \\
\hline & Pearson & ,778** & 396 & 395 & 396 & 396 & 395 & 396 \\
\hline & Correlation & & & & & & & \\
\hline
\end{tabular}




\begin{tabular}{|c|c|c|c|c|c|c|c|c|}
\hline \multirow[t]{4}{*}{ Motivasyon } & $\begin{array}{l}\text { Sig. } \\
\text { tailed) }\end{array}$ & ,000 & ,799** & ,727** & ,693** &, $665^{* * *}$ & 1 & ,741** \\
\hline & $\mathrm{N}$ & 396 & 000 & ,000 & ,000 & ,000 & & ,000 \\
\hline & Pearson &, $551 * *$ & 396 & 395 & 396 & 396 & 395 & 396 \\
\hline & Correlation & & & & & & & \\
\hline \multirow[t]{3}{*}{ İş Tatmini } & $\begin{array}{l}\text { Sig. } \\
\text { tailed) }\end{array}$ & ,000 & ,615** &, $595 * *$ & ,405** &, $538 * *$ & ,741 & 1 \\
\hline & $\mathrm{N}$ & 396 & ,000 & ,000 & ,000 & ,000 & ,000 & \\
\hline & & & 396 & 395 & 396 & 396 & 395 & 396 \\
\hline
\end{tabular}

$0.01 * *$ p $<.01:$ p. $0.05 \square *: p$

Tablo 9'daki veriler incelendiğinde, akademisyenlerin mesleki motivasyon toplam ve alt boyutları ile iş tatmini arasındaki ilişkilerin belirlenmesine yönelik oluşturulmuş korelasyon testi gösterilmektedir. Buna göre katılımcıların mesleki motivasyon alt boyutları ve toplam motivasyon ile genel iş tatmini arasında anlamlı bir ilişki $(p<0,01)$ vardır. Değişkenler arasında doğru yönlü (pozitif) bir ilişkinin olduğu görülmektedir. Buna göre mesleki motivasyonun her bir alt boyutundaki artış toplam motivasyon değerini de artırmaktadır. Bununla birlikte katılımcıların mesleki motivasyonları yükseldikçe genel iş tatminlerinde de artış olduğu görülmüştür.

\section{Sonuç Ve Tartışma}

Akademisyenlerin mesleki motivasyonları mesleki özellikler boyutunda unvana göre anlamlı farkl11ık göstermektedir. Akademisyenlerin unvanlarına göre mesleki özellikler boyutunda mesleki motivasyonlarının anlamlı bir şekilde farklılaştığı söylenebilir. Ünvanı Doç. Dr. olanlarla Arş. Gör ve Öğr. Gör-Okutman-Uzman olanların görüşleri arasında anlamlı fark bulunmuştur. Unvanı, Doç. Dr. olan akademisyenlerden unvanı Arş. Gör. ve Öğr. GörOkutman-Uzman olanlara göre mesleki özellikler boyutunda mesleki motivasyonlarının daha yüksek olduğu ortaya çıkmaktadır. Çalışmada akademisyenlerin mesleki motivasyonları mesleki özellikler boyutunda cinsiyete göre anlamlı farklılık göstermemektedir. Kadın ve erkek akademisyenlerin mesleki motivasyonları mesleki özellikler boyutunda birbirinden anlamlı bir şekilde farklılaşmamaktadır. Akademisyenlerin mesleki motivasyonları yönetim politikaları boyutunda cinsiyete göre anlamlı farklılık göstermemektedir. Çalışmanın 
sonuçlara göre kadın ve erkek akademisyenlerin mesleki motivasyonları yönetim politikaları boyutunda birbirinden anlamlı bir şekilde farklılaşmamaktadır. Karakaya ve Ay (2007) tarafından yapılan çalışmada, yönetimle iletişim kurabilme ve işin tekdüze olmaması ile ilgili faktörlerin, çalışanların motivasyonu üzerinde çok önemli etkisi olduğu sonucu ortaya çıkmıştır. Çalışanların yaş boyutu açısından incelendiğinde ise, iş yerinde ilişkiler faktörü anlamlı bulunmuştur. 35 yaş ve altındaki çalışanlara göre ise iş yerinde ilişkiler boyutu motivasyon artırıcı öneme sahiptir. Çalışmamızda ise 40 yaş ve altı çalışanlar iş yerinde ilişkiler boyutunu daha az önemsedikleri sonucuna varılmıştır. $\mathrm{Bu}$ iki çalışma kıyaslandığında, farklı mesleklerin, iş ortamları ve boyutları, çalışanların motivasyon düzeylerini farklı bir şekilde etkilediğini ortaya koymaktadır.

Ortalama motivasyon düzeyine bakıldığında akademisyenlerin mesleki özelikler, iş yerinde ilişkiler boyutlarının ortalama motivasyon düzeyinden daha yüksek; yönetim politikaları, öğrenci ve fiziksel koşullar boyutlarının ise daha düşük değerlere sahip oldukları görülmektedir. Akbaba ve Demir (2015), Sat (2011) ile Dağdeviren ve Musaoğlu, Ömürlü, Öztora, (2011). çalışmalarında ise erkek çalışanların kadın çalışanlara göre daha yüksek iş tatminine sahip oldukları görülmüştür. Yukarıdaki bulgulara ilişkin olarak, kadın akademisyenlerin iş yerinde ilişkiler boyutunda daha az motive olmalarının nedenleri arasında, kadın akademisyenlerin erkek akademisyenlere göre çok yönlü bir hayat tarzına sahip olmalarından kaynaklandığı söylenebilir. Kadın çalışanların erkek çalışanlara oranla daha düşük düzeyde tatmin olmalarına ilişkin Eğinli (2009), tarafından yapılan bir çalışmada, kadınların birincil sorumluluk alanı olarak "evi” ifade ettiklerinden iş tatmini konusunda erkeklere göre düşük iş tatmin düzeyi gösterdikleri, erkeklerinse birincil sorumluluk alanı olarak "işi” tanımlamaktadır. $\mathrm{Bu}$ durum cinsiyete göre değerlendirildiğinde, çalışanlar arasında farklı olumlu tutum gösterdikleri sonucuna varılmıştır. Bu sonuçlardan hareketle, çalışanlar arasında cinsiyete göre bir farklılık mevcut olup, bu da erkek çalışanlar lehine yüksek iş tatmin düzeyi olarak ortaya çıkmıştır.

Akademisyenlerin mesleki motivasyonları iş yerinde ilişkiler boyutunda kıdeme göre anlamlı farklılık göstermektedir. Akademisyenlerin kıdemlerine göre iş yerinde ilişkiler boyutunda mesleki motivasyonlarının anlamlı bir şekilde farklılaştığı söylenebilir. Akademisyenlerden 21 yıl ve üzeri kıdeme sahip olanlarla 11 yıl ve 20 yıl kıdeme sahip olanlar arasında anlamlı fark bulunmuştur. 21 yıl ve üzeri kıdeme sahip olanların ,11 yıl ve 20 yıl kıdeme sahip olanlara göre iş yerinde ilişkiler boyutunda mesleki motivasyonlarının daha yüksek olduğu ortaya çıkmıştır. 
Akademisyenlerin mesleki motivasyonları öğrenci boyutunda cinsiyete göre anlamlı farklılık göstermemektedir. Kadın ve erkek akademisyenlerin mesleki motivasyonları öğrenci boyutunda birbirinden anlamlı bir şekilde farklılaşmamaktadır. Kadın ve erkek akademisyenlerin mesleki motivasyonları toplam motivasyon boyutunda birbirinden anlamlı bir şekilde farklılaşmadığı ortaya çıkmıştır. Akademisyenlerin mesleki motivasyonları öğrenci boyutunda kıdeme göre anlamlı farklılık göstermemektedir. Akademisyenlerden 21 yıl ve üzeri kıdeme sahip olanlarla 10 yıl ve altı kıdeme sahip olanlar arasında anlamlı fark bulunmuştur. 21 yıl ve üzeri kıdeme sahip olanların 0.42 puan farkla 10 yıl ve altı kıdeme sahip olanlara göre fiziksel koşullar boyutunda mesleki motivasyonlarının daha yüksek olduğu ortaya çıkmaktadır.

Akademisyenlerin mesleki motivasyonları öğrenci boyutunda unvana göre anlamlı farklılık göstermektedir. Buna göre akademisyenlerin unvanlarına göre öğrenci boyutunda mesleki motivasyonlarının anlamlı bir şekilde farklılaştığı görülmüştür Akademisyenlerden unvanı Doç. Dr. olanlarla Arş. Gör olanlar arasında anlamlı fark bulunmuştur. Unvanı Doç. Dr. olan akademisyenlerin unvanı Arş. Gör. olanlara göre öğrenci boyutunda mesleki motivasyonlarının daha yüksek olduğu ortaya çıkmaktadır.

Akademisyenlerin mesleki motivasyonları toplam motivasyon boyutunda yaşa göre anlamlı farklılık göstermektedir. Sonuçlar incelendiğinde, 40 yaşın altında ve 40 yaşın üzerindeki akademisyenlerin mesleki motivasyonları toplam motivasyon boyutunda birbirinden anlamlı bir şekilde farklılaşmaktadır. Bu boyuttaki aritmetik ortalamalar dikkate alındığında, farkın; 0,17'lik bir farkla 40 yaş ve üzeri akademisyenlerin lehine olduğu görülmektedir. 40 yaş ve üzeri akademisyenlerin 40 yaş ve altı akademisyenlerin göre, fiziksel koşullar boyutunda mesleki motivasyonlarının daha yüksek olduğu söylenebilir.

Akademisyenlerin mesleki motivasyonları fiziksel koşullar boyutunda eğitim durumuna göre anlamlı farklılık göstermektedir. Akademisyenlerin eğitim durumlarına göre fiziksel koşullar boyutunda mesleki motivasyonlarının anlamlı bir şekilde farklılaştığı söylenebilir. Akademisyenlerden eğitim durumu doktora olanlarla lisans olanlar arasında anlamlı fark bulunmuştur. Eğitim durumu doktora olanların 0.70 puan farkla eğitim durumu lisans olanlara göre fiziksel koşullar boyutunda mesleki motivasyonlarının daha yüksek olduğu ortaya çıkmaktadır.

Akademisyenlerin mesleki motivasyonları fiziksel koşullar boyutunda unvana göre anlamlı farklılık gösterdiği bulunmuştur. Akademisyenlerin unvanlarına göre fiziksel koşullar 
boyutunda mesleki motivasyonlarının anlamlı bir şekilde farklılaştığı söylenebilir. Akademisyenlerden unvanı Prof. Dr. olanlarla Arş. Gör olanlar arasında anlamlı fark bulunmuştur. Unvanı Prof. Dr. olan akademisyenlerin, unvanı Arş. Gör. olanlara göre fiziksel koşullar boyutunda mesleki motivasyonlarının daha yüksek olduğu ortaya çıkmaktadır.

Akademisyenlerin mesleki motivasyonları toplam motivasyon boyutunda unvana göre anlamlı farkl1l1k göstermektedir. Akademisyenlerin unvanlarına göre toplam motivasyon boyutunda mesleki motivasyonlarının anlamlı bir şekilde farklılaştığı söylenebilir. Akademisyenlerden unvanı Doç. Dr. olanlarla Arş. Gör. olanlar arasında anlamlı fark bulunmuştur. Unvanı Doç. Dr. olan akademisyenlerin unvanı Arş.Gör. olanlara göre toplam motivasyon boyutunda mesleki motivasyonlarının daha yüksek olduğu ortaya çıkmaktadır.

Araştırmamızda Akademisyenlerin çalıştı̆ğ birime göre fiziksel koşullar boyutunda anlamlı farklılık bulunmuştur bunun sebepleri ise yüksekokulda çalışan akademisyenlerin, fakültede çalışan akademisyenlere göre kendilerini daha dezavantajlı olarak görmelerinden kaynaklanabilir. Çünkü yüksek okulların ekseriyetle ilçelerde bulunması, ulaşım, sosyal olanaklar, çocuklu çalışanların çocuklarının aldığı eğitim-öğretim vb. durumlar yüksekokul çalışanlarının motivasyon düzeylerini etkilediği ortaya çıkmıştır. Literatürde yapılan çalışmalarda, Hotamışlı ve Ağca (2010), Tor (2011) ve Zeynel (2014), akademisyenlerin çalıştıkları birimlere göre motivasyon düzeyleri arasında farklılık bulunurken, Gürkan (2006) tarafından akademisyenlere yönelik yapılan çalışmada, akademisyenlerin çalıştığı birime göre motivasyon düzeylerinde farklılık saptanmamıştır. Katılımcı akademisyenlerin çalıştığı birime göre iş tatmin düzeylerine bakıldığında yüksekokul ya da fakültede çalışan akademisyenlerin görüşleri arasında anlamlı farklılık görülmemiştir ( $\mathrm{p}>.05)$. Bilge, Akman \& Kelecioğlu, (2007), Yelboğa (2007) ve Sezgin 2010)'in yaptığı çalışmalarda da, yaşın ilerlemesi ile birlikte iş tatminin de arttı̆̆ belirlenmiştir.

Akademisyenlerin mesleki motivasyonları fiziksel koşullar boyutunda yaşa göre anlamlı farklılık göstermesinin nedeni olarak yaşın verdiği olgunluk ile birlikte, aşırıya gitmeyen talepler ve karşılanmaması durumunda ise huzursuzluk ya da tatminsizlik oluşturmayan tepkiler görülebilir. Aynı zamanda birçok beklentisi olan, zamanında ya da hiç karşılanmayan ihtiyaç ve beklentiler, 40 yaşın altındaki çalışanları olumsuz etkilemekte ve bununla birlikte motivasyonlarını düşürmektedir denilebilir.

Akademisyenlerin eğitim durumu değişkenine göre motivasyon düzeyleri arasında anlamlı bir farkın görülmesi nedenleri arasında, akademisyenlerin akademik süreç içerisinde elde ettiği bilgi, birikim, deneyim ve alanda uzmanlaşma ile birlikte bireyde oluşan özgüvenle ifade 
edilebilir. Doktora yapan akademisyenlerin iş arkadaşları ve öğrenciler ile kurulan etkili iletişimin sonucunda, oluşan samimi hava da bir artı olarak değerlendirilebilir. Diğer bir neden olarak da, örgütün doktora yapan öğretim elemanlarına sunduğu fiziksel olanaklardaki ayrıcalıktan ya da hizmetten de kaynaklanabilir. Alanda yapılan çalışmalar Derin (2007), Demir (2010), Sezgin (2010), Telef (2011), Sat (2011), Tor (2011) ve Mahmutoğulları (2015) incelendiğinde de, eğitim düzeyi yükseldikçe motivasyon düzeyinin de artığı görülmüştür. $\mathrm{Bu}$ sonuç bizim sonuçlarımızla benzerlik göstermektedir.

Akademisyenlerin mesleki motivasyonları ve iş tatmin düzeyleri arasındaki ilişkiyi ortaya çıkarmaya dönük yapılan bu çalışmada; Akademisyenlerin mesleki motivasyon alt boyutları incelendiğinde, kendi gayretleri sonucu elde edilen mesleki özellikler boyutunda mesleki motivasyonlarının yüksek düzeyde, örgütün yönetim politikaları sonucu çalışanların kişisel ihtiyaçlarının karşılanmaması sonucu mesleki motivasyonlarının daha düşük düzeyde olduğu görülmüştür. Ağırbaş, Çelik \& Büyükkayıkçı, (2005) tarafından yapılan bir çalışmada, çalışanların işlerine karşı olan tutum ve davranışları, çalışma koşulları ve örgütün yönetim anlayışı gibi etkenler, çalışanların mesleki motivasyonlarını etkilediği, olumlu yönde ilerlediğinde ise iş tatmin düzeylerini de buna bağlı olarak artırdığg görülmüştür. Platis ve diğerlerinin(2014) ile Chao ve diğerlerinin (2013) yılında hastane çalışanları ile yaptığı çalışmada da, iş tatmininin ödüllendirilme ve çalışma şartları boyutlarının işgören performansını pozitif yönde etkilemesi bakımından bu çalışmaların sonuçları ile benzerlik göstermektedir. İş tatmini boyutlarından yöneticiden memnuniyetin iş gören performansı boyutlarından yapılan işin kalitesi boyutu ile pozitif bir ilişki olduğu sonucu tespit edilmiştir. Bu sonuç bizim sonuçlarımızla örtüşmektedir.

İş tatmin düzeylerine bakıldığında ise, katılımcı akademisyenlerin görüşleri arasında anlamlı bir fark bulunmamıştır ( $\mathrm{p}>.05)$. Göreceli olarak aritmetik ortalamalara bakıldığında ise yüksek lisans eğitim düzeyi grubundaki katılımcı akademisyenlerin diğer gruplara göre iş tatmin düzeylerinin daha düşük olduğu sonucu ortaya çıkmıştır. İş yerinde geçirilen yaşantıların, çalışanların iş tatmini üzerindeki etkileri ile ilgili yapılan araştırmalar incelendiğinde, çalışmamız; Sezgin (2010), Tor (2011) ve Mahmutoğulları (2015) yapılan bu çalışma ile yüksek oranda, Akman, Kelecioglu, \& Bilge (2006), Toker (2007), Yelboğa (2007), Sezgin (2010), Tor (2011), Telef (2011), Zeynel (2014), tarafından yapılan çalışmalarda da, iş yerinde geçirilen sürenin uzaması (kıdem) ile iş tatmin düzeyinin artışı arasında orta düzeyde tutarl11ık görülmüştür. 
Yukarıda verilen bilgiler göz önüne alındığında, ölçeğe katılanların genel iş tatmin puanı ise 76 'dır. Buna göre akademisyenlerin iş tatminlerini ölçmeye yönelik yapılan betimsel istatistik analizi sonuçlarına göre katılımcı öğretim üyelerinin genel iş tatmin düzeyleri yüksek seviyededir. Akademisyenlerin genel iş tatmini boyutu cinsiyete göre anlamlı farklılık göstermemektedir. Buna göre kadın ve erkek akademisyenlerin genel iş tatminleri birbirinden anlamlı bir şekilde fark göstermediğidir. Akademisyenlerin genel iş tatmini boyutu yaşa göre anlamlı farklılık göstermektedir. 40 yaşın altında ve 40 yaşın üzerindeki akademisyenlerin iş tatminleri birbirinden anlamlı bir şekilde farklılaşmaktadır. Bu boyuttaki aritmetik ortalamalar dikkate alındığında, farkın; 0,17'lik bir farkla 40 yaş ve üzeri akademisyenlerin lehine olduğu görülmektedir. 40 yaş ve üzeri akademisyenlerin 40 yaş ve altı Akademisyenlere göre genel iş tatminlerinin daha yüksek olduğu söylenebilir.

Akademisyenlerin genel iş tatminleri eğitim durumuna göre anlamlı farklılık göstermemektedir. Buna göre akademisyenlerin eğitim durumlarına göre genel iş tatminlerinin anlamlı bir şekilde farklılaşmadığ s söylenebilir. Akademisyenlerin genel iş tatminleri unvana göre anlamlı farkl1lık göstermektedir. Akademisyenlerin unvanlarına göre genel iş tatminlerinin anlamlı bir şekilde farklılaştığı söylenebilir. Akademisyenlerden unvanı Doç. Dr. Olanlarla, Arş. Gör. olanlar arasında anlamlı fark bulunmuştur. Unvanı Doç. Dr. olan akademisyenlerin, unvanı Arş. Gör. olanlara göre genel iş tatminlerinin daha yüksek olduğu ortaya çıkmaktadır.

Akademisyenlerin mesleki motivasyon boyutu ile genel iş tatmini arasında anlamlı bir ilişki vardır. Değişkenler arasında doğru yönlü (pozitif) bir ilişki vardır. Diğer bir ifade ile katılımcıların mesleki motivasyonları yükseldikçe genel iş tatminlerinde de artış olmaktadır. $\mathrm{Bu}$ durum da gösteriyor ki, motivasyon araçları ile motive edilen çalışanların genel olarak iş tatmin düzeylerinin de artış gösterdiği, çalışanların ile hem örgüt hem de işleri arasında olumlu bir bağ kurulmuştur.

Sonuç olarak, alanda yapılan tüm çalışmalardan elde edilen veriler gösteriyor ki, çalışanın memnuniyeti ve tatmin düzeyi, aynı zamanda örgütün de etkililiği, verimliliği ve başarısı ile doğru bir seyir izler. Bir örgüt içerisinde çalışanların tatmininin sağlanması, yönetimin en önemli görevlerinden biri olmalıdır. İş görenlerin tatmin edilmesi, kuruma bağlılığı ve kaliteyi arttıracaktır. Bundan dolayı kurum yöneticilerinin iş tatmini ortaya çıkaracak stratejiler oluşturmaya yönelik uğraşı içerisinde olmaları gerekir. Akademisyenlerin, mesleki motivasyon ve iş tatmin düzeylerinin artışı, örgüt yönetimi tarafından önemsenen maddi manevi tatminlerle ihtiyaçları giderilen çalışanlar ile mümkün olduğu sonucuna ulaşılmıştır. 
Örgütler, çalışanların örgüte sunduğu hizmete karşılık, çalışanlara verdiği (karşılanan her türlü ihtiyaç) dönüt oranında başarılı olduğu çalışmamızda ve birçok çalışmada ortaya çıkan bulgulardan anlaşılmaktadır.

\section{Öneriler}

Çalışanın memnuniyeti ve tatmin düzeyi, aynı zamanda örgütün de etkililiği, verimliliği ve başarısını önemli ölçüde etkilediğinden yöneticilerin memnuniyet konusunda bütün ihtiyaçları karşılayıcı tedbirleri almalıdırlar.

Yöneticiler araştırma ve öğretim görevlerinin iş tatminlerini artırıcı maddi ve manevi özendiricileri daha fazla kullanmalıdırlar.

Akademisyenlerin mesleki motivasyonları fiziksel koşullar sürekli olarak gözden geçirilmeli ve ihtiyaçlar isteğe bağlı iyileştirilmelidir.

Çalışanların hizmet içi eğitimlerine önem vererek, onları kongre, sempozyum, çalış tay vb. çalışmalara teşvik etmeli ve gerekli desteği sağlamalıdırlar.

Akademisyenler arasında unvana göre hizmet ayrımcılı̆̆ akademisyenler arasında adaletsizlikler ortaya çıkarmakta, motivasyon ve iş tatmin düzeylerini anlamlı bir şekilde düşürücü rol oynamakta olduğundan bu tür uygulamalara son verilmelidir.

Araştırma görevlileri ile öğretim görevlilerin çalışma koşulları en kısa süre beklentileri ve ihtiyaçları doğrultusunda iyileştirilmeli, alınan kararlara onlar da katılmalı, mevzuatta yer alan sınırlayıcı, zorlayıcı ve katı durumlar ya düzeltilmeli ya da ilgililere bu sorunun çözümü için gerekli çalışmalar yapılmalıdır.

Akademisyenler arasında var olan iletişim engelleri ve diğer engeller yönetim tarafından tespit edilip giderilmeye çalışılmalı, özellikle bayan akademisyenlerin motivasyon düzeylerini düşüren 'iş yerinde ilişkiler’ boyutu için yönetim kapsamlı tedbirler almalıdır.

Akademisyenlerin; mesleki motivasyon ile iş tatmin düzeylerini etkileyen iş yerinde biri birlerinden kopuk yaşadığı, birbirlerini ziyaret etmedikleri, ortaya çıktığından yönetim birimlerince bu problemi ortadan kaldıracak sosyal faaliyetlere yer verilerek birimlerde beşeri sermaye oluşturulmalıdır. 


\section{Makalenin Bilimdeki Konumu}

Eğitim Yönetimi Denetimi Ekonomisi ve Planlaması ABD

\section{Makalenin Bilimdeki Özgünlüğü}

$\mathrm{Bu}$ araştırmada, akademisyenlerin mesleki motivasyonları ile iş tatminleri arasındaki ilişki düzeyleri belirlenerek uygulamalarında karşılaşılan sorunlar boyutlarındaki cevapları değerlendirilmeye alınmıştır. $\mathrm{Bu}$ yönüyle ortaya çıkan sonuçlar literatüre katkı sağlamasının yanı sıra akademisyen yetiştirmede alınabilecek önlemler hakkında da ilgililere fikir verici bir niteliktedir. Ülkemizde konu ile ilgili çalışmalara az rastlanmaktadır

\section{KAYNAKÇA}

Ağırbaş, İ. Çelik, Y. \& Büyükkayıkçı, H. (2005). Motivasyon araçları ve iş tatmini: sosyal sigortalar kurumu başkanlığı hastane başhekim yardımcıları üzerinde bir araştırma. Hacettepe Să̆lık İdaresi Dergisi, (Cilt 8, Sayı:3).

Akbaba, A. \& Demir, S. (2015). Eğitim fakültesinde görev yapan öğretim elemanlarının örgütlerindeki memnuniyet düzeyleri. Türk \& İslam Dünyası Sosyal Araştırmalar Dergisi Yıl: 2, Sayı: 2, Mart 2015, s. 237-287

Akman, Y. Kelecioglu, H. \& Bilge, F. (2006). Öğretim Elemanlarının İş Doyumlarını Etkileyen Faktörlere İlişkin Görüşleri. Hacettepe Üniversitesi Eğitim Fakültesi Dergisi (Cilt 30, Sayl:17. s. 20).

Baycan, A. (1985). An Analysis of Several Aspects of Job Satisfaction Between Different Occupational Groups, Boğaziçi Üniversitesi Yayınlanmamış Yüksek Lisans Tezi, İstanbul.

Bilge, F. Akman, Y. \& Kelecioğlu, H. (2007). Öğretim elemanlarının iş doyumlarının 
incelenmesi, Hacettepe Üniversitesi Ĕ̈itim Fakültesi Dergisi, Cilt. 32, s. 41.

Büyüköztürk, Ş. (2016). Bilimsel araştırma yöntemleri.21.Baskı, Ankara: Pegem

Akademi yayınc1lık.

Cemaloğlu, N. (2012). (Edt. A.Tanrıöğen,). Bilimsel araştırma yöntemleri. Ankara: Anı Yayınc1lık

Chao, M.C., Jou, R.C., Liao, C.C. \& Kuo, C.W. (2015). Workplace stress, job satisfaction, job performance, and turnover intention of health care workers in rural Taiwan. Asia-Pacific Journal of Public Health, 27(2), 1827-1836.

Dağdeviren, N. Musaoğlu, Z. Ömürlü, İ.K. \& Öztora, S. (2001). Akademisyenlerde iş doyumunu etkileyen faktörler. Balkan Med Dergisi, (Sayı 28, s. 69-74).

Derin, N. (2007). Devlet hastanelerinde çalışan sağlık personelinin iş tatmin düzeyleri ve etkileyen faktörler. Yüksek Lisans Tezi.

Eğinli, A.T.(2009).Çalışanlarda iş doyumu: kamu ve özel sektör çalışanlarının iş doyumlarına yönelik bir araştırma. Atatürk Üniversitesi İktisadi ve İdari Bilimler Dergisi, (Cilt 23, Sayl:3),

Eren, E. (2012). Örgütsel davranış ve yönetim psikolojisi. Ankara: Beta Yayıncılık.

Gezici, H. S. (2012). Belediyelerde örgüt kültürü araştırması: Selçuklu belediyesi örneği. Yüksek Lisans Tezi.

Gürkan, G. Ç. (2006). Örgütsel bă̆gllık: Örgütsel iklimin örgütsel bağglılı üzerindeki etkisi ve Trakya Üniversitesi’nde örgüt iklimi ile örgütsel bağlılık arasındaki ilişkinin araştırılması. Yüksek Lisans Tezi.

Hotamışlı, M. \& Ağca, V. (2010). Öğretim elemanlarını iş tatmin düzeylerinin 
demografik özelliklere göre değişmesi: Türkiye'de kamu ve vakıf üniversitelerinde karşış̧̧ııılmalı bir araştırma. Sosyal Bilgiler Dergisi, (Cilt 12, Sayl:2), Afyonkarahisar

Kaptan, S. (1995). Bilimsel araştırma ve istatistik teknikleri. Ankara: Tekışık Web Ofset Tesisleri.

Karakaya, A.\& Ay, F. (2007). Çalışanların motivasyonunu etkileyen faktörler: sağlık çalışanlarına yönelik bir araştırma. C.Ü. Sosyal Bilimler Dergisi,( Cilt 31,Sayl:1,s. 55).

Karasar, N. (1995). Araştırmalarda rapor hazırlama, Ankara: 3A Araştırma Eğitim Danışmanlık Limited.

Keser, A. (2008). Çalışma yaşamı ile yaşam doyumu ilişsisine teorik bakış. Kocaeli Üni. İIBF.

Kılıç, M. (2014). (Edt. B.Yeşilyaprak,). Eğitim psikolojisi. 12.Baskı, Ankara: Pegem Akademi Yayınc1lık.

Koçel, T. (2001). İşletme yöneticiliği. 8. Basım, İstanbul: Beta Yayıncılık.

Mahmutoğulları, D. (2015). Hizmet içi eğitim algısının işgörenlerin öğrenme motivasyonları üzerindeki etkisi: Bodrum örneği. Yüksek Lisans Tezi.

Platis, C.H., Reklitis, P. \& Zimeras, S. (2015). Relation between job satisfaction and job performance in healthcare services. Social and Behavioral Sciences, 175, 480- 487

Sat, S. (2011). Örgütsel ve bireysel özellikler açısından iş doyumu ile tükenmişlik düzeyi arasındaki ilişki: alanya'da banka çalışanları üzerinde bir inceleme. Çukurova Üniversitesi Sosyal Bilimler Enstitüsü İşletme Anabilim Dalı, Y. Lisans Tezi. Adana.

Sezgin, A. (2010). Üniversite hastanelerinde çalışan başmüdür ve müdürlerin iş tatminu ile tükenmişlik düzeylerinin incelenmesine yönelik bir araştırma. Yüksek Lisan Tezi. 
Sun, H. Ö. (2002). İ̧̧ doyumu üzerine bir araştırma: türkiye cumhuriyet merkez bankası banknot matbaasl genel müdürlüğ̈̈. Uzmanlık Yeterlilik Tezi.

Telef, B.B. (2011). Öğretmenlerin öz-yeterlikleri, iş doyumları, yaşam doyumları ve tükenmişliklerinin incelenmesi. Illköğretim Online, (Cilt 10,Sayı:1,s. 91-108).

Toker, B. (2007). Demografik değişkenlerin iş tatminine etkileri: İzmir'deki beş ve dört yıldızlı otellere yönelik bir uygulama. Doğuş Üniversitesi Dergisi, (Cilt 8 Sayı:1,s. 92).

Tor, S.S. (2011). Örgütlerde iş tatminini etkileyen demografik faktörler ve verimlilik:

Karaman gıda sektöründe bir uygulama

Yavuz, C. \& Karadeniz, C. B. (2009). Sınıf öğretmenlerinin motivasyonunun iş tatmini üzerine etkisi. Uluslararası Sosyal Araştırmalar Dergisi, (Cilt 2,Sayı: 9).

Yelboğa, A. (2007). Bireysel demografik değişkenlerin iş doyumu ile ilişkisinin finans sektöründe incelenmesi. Sosyal Bilimler Dergisi, (Cilt 4, Sayı:2).

Zeynel, E. (2014). Akademisyenlere yönelik mesleki motivasyon, iş tatmini ve örgütsel bă̆lllık arasındaki ilişkiler üzerine bir araştırma. Süleyman Demirel Üni. Doktora Tezi.

\section{Summary}

\section{Statement of Problem}

This research aims to determine the organizational problems faced by academicians while performing their professions, the failure to meet the needs and expectations that must be met as individuals, the factors that reduce the motivation of academicians and disturb them in their institutions, and the factors that reduce their job satisfaction levels. Furthermore, to find out the relationship between occupational motivation and job satisfaction, to increase motivation levels of the staff and to make proposals in order to improve efficiency, productivity and 
quality in education, administration and the other fields with the intention of raising job satisfaction levels were set as the main objectives of the study.

\section{The purpose of the study}

The purpose of this study is to determine the level of relationship between the occupational motivations and job satisfactions of academicians. In this direction, answers to the following questions are sought.

1- What is the level of the occupational motivations and job satisfaction of academicians?

2- How is the relationship between academicians' occupational motivations and job satisfaction?

3- What is the level of academicians' occupational motivations in Professional Qualifications, Management Policies, and Relations at the Workplace, Student Characteristics and Physical Conditions of the workplace sub-dimensions? Do they show differences in terms of age, gender, length of service, educational level, and position at work or title of the academicians?

4- What is the level of academicians' job satisfaction in Professional Qualifications, Management Policies, and Relations at the Workplace, Student Characteristics and Physical Conditions of the workplace sub-dimensions? Do they show differences in terms of age, gender, length of service, educational level, and position at work or title of the academicians?

\section{Methodology}

A scale was employed in the research. The scales were applied to all members of the study population face-to-face. Before evaluating the scale data, it was checked whether the obtained scales were responded appropriately or not and the appropriately responded scales were evaluated. Descriptive factor analysis, t-test, anova analysis and correlation analysis of the data obtained from the scales were performed with an appropriate package program.

\section{The Population and Sampling of the Study}

The research population is all the academicians working at Yüzüncü Y1l University while the sample group composed of only the academicians who applied the scale. Before initiating the 
research, the units located in and outside of Yüzüncü Y1l University campus and the units located in the other districts of the city were determined.

At the time of the research, it was aimed to apply the scales to the total number of 1318 academicians consisting of 93 professors, 119 associate professors, 462 assistant professors, 138 lecturers / experts and 506 research assistants, at Yüzüncü Y1l University. However, the researchers could reach 563 academicians and hand in the study scales. 430 of the questionnaires were answered and returned by the academicians. The return rate was around $66 \%$. Of the 430 scale forms returned, 396 questionnaires were fully filled and found suitable for analysis. Research is a descriptive study of quantitative research methods. The scale was randomly applied to the whole universe.

The sample size considering the universe size should be at least 333 for a 5\% sampling error in the 95\% confidence interval (Baş, 2010: 41). This condition has been met according to the results of the research. At first, it was aimed to reach a number between 333 and 500 for sample group. It is considered that by reaching 396 people which is between of 333 lower and 500 upper limits as the target sampling interval, the estimated 5\% error margin for the 95\% confidence interval is further reduced.

\section{Suggestions}

The working conditions of research assistants and lecturers should be improved considering their needs and expectations as soon as possible. Moreover, they must be able to take part in decision-making process actively and the restrictive, compelling and strict regulations should be improved or authorities should be informed to solve these problems.

Communication obstacles among the academicians and the other obstacles should be determined and overcome by the management. Management must strive for a comprehensive solution considering the sub dimension of "Relations at the workplace', which reduces the motivation levels of female academicians.

The starting point of these efforts should be the findings obtained from the studies conducted about the topic and the work as a priority for the male academicians and the home as a priority for the female academicians should be taken into consideration 
Facilities considering female academicians' children such as kindergarten, playground, kids' clubs etc. should be provided and more social activities for female academicians should be organized since they have to allocate their time to their children and housework as well as their work. As a result, considering the 'Relations at Work' sub dimension new regulations should be applied in order to increase the motivation level of the female academicians.

It is necessary for the management to take the necessary precautions about the issue since the employees of the organizations appreciate the spiritual awards more than the material awards and the spiritual awards provide more motivation and thus the academicians create a satisfying feeling and raise positive motivation towards the work.

Since academicians don't visit their colleagues, take part in common social activities with them or don't spend time together, very low level was observed in sub dimension of 'Relations at Work' in the study. As a result, managers of these institutions should organize intimate activities in order to bring the academicians together and improve their relationship among themselves. 